\title{
Women Academic Library Leadership in Pakistan: A Qualitative Study on the Journey of Career Progression and Serving the Community
}

\section{Murtaza Ashiq, Shafiq Ur Rehman, Sadaf Rafiq, and Muhammad Tariq}

\begin{abstract}
Women library professionals are greatly underrepresented in key leadership positions, especially in the developing countries. This study explored the women academic library leadership in Pakistan and investigated the major challenges faced by women leaders during their ascending to the top, the key indicator of their success, as well as the community services and professional contributions made by them during the course of their careers. Qualitative research design was used and data were collected by conducting in-depth interviews of 16 senior woman library leaders in Pakistan. The findings indicated that organizational challenges, family responsibilities, and gender discrimination were the major barriers that hindered the women leaders during their career progression. The key indicators of their success were effective use of technology, professional commitment, academic contributions, community services, family support, international exposure, and continuous learning. The implications of the study highlight the various areas of improvement for women library leadership.
\end{abstract}

\section{Introduction}

Librarianship is commonly considered to be a feminized profession in most of the developed world. ${ }^{1}$ According to Deyrup, women started to enter the Library and Information Science (LIS) profession in the mid-nineteenth century in America. ${ }^{2}$ These women generally belonged to middle-class working families and were recruited by male library directors to work in the libraries, as they offered a very competent and cost-effective labor force at the time. Consequently, nearly 90 percent of the library positions in the country were being filled by women by the year $1920 .{ }^{3}$ However, even though they comprised a majority of the workforce within the profession throughout the twentieth century, there were limited numbers of women in leadership positions in librarianship at the time. They were also being paid lower wages as

\footnotetext{
${ }^{*}$ Murtaza Ashiq is PhD Scholar, Institute of Information Management, University of the Punjab, Quaid-eAzam Campus, Lahore; Lecturer, Library and Information Science at Islamabad Model College for Boys, email: gmurtazaashiq00@gmail.com. Shafiq Ur Rehman is Associate Professor, Institute of Information Management, University of the Punjab, Quaid-e-Azam Campus, email: Shafiq.im@pu.edu.pk. Sadaf Rafiq is Librarian, Central Library, at Govt. College University; email: sadaf.rafiq12@hotmail.com. Muhammad Tariq is Incharge, Library Information Services, at COMSATS University; email: tariqnajmi@cuilahore.edu.pk. (02021 Murtaza Ashiq, Shafiq Ur Rehman, Sadaf Rafiq, and Muhammad Tariq, Attribution-NonCommercial (https://creativecommons. org/licenses/by-nc/4.0/) CC BY-NC.
} 
compared their male counterparts. ${ }^{4}$ DeLong reported that, in the year 1970, there was not a single woman head of a library in the Association of Research Libraries (ARL). ${ }^{5}$

We are now observing a significant increase in the number of women who have been recruited to leadership positions in the profession. A study conducted by Moran, Leonard, and Zellers indicated that the number of women LIS professionals in leadership positions was on the rise in the United States, especially within the ARL, where 60 percent of the leadership positions were held by women. ${ }^{6}$ Despite these numbers, the LIS profession is once again gradually transitioning toward male-dominant leadership since the start of the twenty-first century. ${ }^{7}$ Apparently, the situation of professional jobs and leadership positions for women is quite contrary to this in the developing countries and among minority groups. McLinn examined the literature on African-American women in leadership positions and highlighted the fact that there was no published work on the representation of African-American women in the ARL library leadership. ${ }^{8}$ Wheeler indicated that most of the efforts undertaken by the professional leadership were only aimed at recruiting minorities into the profession. ${ }^{9}$ No significant efforts were being made to groom them for leadership roles and none whatsoever to promote them into such roles. Epps reported that, while the African-American and minority library professional women required the same set of nonminority library skills, they also required additional attributes that would allow them to overcome the racial stereotypes in the professional environment. ${ }^{10}$

This is equally important in the male-dominant library environment prevalent in developing countries, especially in Pakistan. According to the Global Economy data, Pakistan has remained at the bottom of the list in terms of female labor force participation in the workforce. The female labor force ranking list of 2019 showed that Pakistan was ranked 171 among 182 countries, and ranked 38 ranked among the 46 Asian countries on the list. ${ }^{11}$ Many studies conducted in the developing countries' context have highlighted the underrepresentation of females in the LIS profession in the developing world. ${ }^{12}$ According to official websites of Higher Education Commission (HEC), Pakistan's recognized universities and degree-awarding institutes, approximately only 18 percent of the university libraries currently have a woman in the leadership position. ${ }^{13}$ Farooq, Ullah, Iqbal, and Hussain indicated that the female academic library professionals in Pakistan appeared to lack certain professional competencies as compared to their male colleagues. They suggested that policy makers should develop and implement such policies and guidelines that help foster a "favorable environment" to encourage the entry of women in the profession. ${ }^{14}$ Khan, Anbareen, Idrees, and Saeed described that the readiness to take gender into the mainstream had been compromised due to challenges like societal norms, organizational constraints, and lack of capacity-building opportunities. ${ }^{15}$

Overall, there are limited numbers of studies that describe the challenges being encountered by women library leaders in their career progression, and few describe their services and key elements of their success. ${ }^{16}$ Akpebu Adjah and Van der Walt examined the career progression of female librarians in Ghana and revealed that the females were unable to meet the promotion criteria due to various challenges such as societal expectations from females, age, responsibilities of being working women, and the inability to stay involved in continuous professional development activities. This ultimately resulted in slower career progression of female librarians and excluded them from availing the top leadership opportunities. ${ }^{17}$

There is a general lack of women in leadership positions in the library profession; however, there has been limited research done to investigate the challenges faced by female library 
leaders and the trajectory of their career progression, especially in the developing countries' context, where a majority of the leadership positions are held by male library professionals. Therefore, this study will address this gap in the literature and explore the status of women academic library leadership in Pakistan. The study highlights the major challenges being faced by women library leaders, their success stories in reaching their current position, their services to the community and their professional contribution at the national and the international level. The study will address the following research questions:

1. What types of barriers are being faced by Pakistani women library leaders in the profession?

2. What are the key indicators of their success to reach their existing leadership positions?

3. What kinds of community services are being offered by women academic library leaders?

4. What are the academic and professional contributions of Pakistan women library leaders?

\section{Literature Review}

\section{Challenges of Women Library Leadership}

Every segment of life has its own opportunities and challenges. Likewise, women library leadership has different challenges in their professional as well as personal life. As Stokes et al. stated, the challenges faced by women working in academic libraries had five broad dimensions: opportunities, behavior, socializing, personal life, and remediation policies and practices. Furthermore, they were also offered less advice and support as compared to their male counterparts in the workplace. ${ }^{18}$ Interestingly, Chapman revealed that, overall, 42 percent of the negative comments were directed toward women applicants with statements like "not the right man for the job" or that they were just "token applicants." ${ }^{19}$ Similarly, Holden defined the term "tokenism" for women and described it to be the reason for the inability of women to move beyond the middle management positions to top management positions. ${ }^{20}$ The existence of discrimination against women and their marginalization in the workplace has resulted in the overall poor representation of women in top management positions. ${ }^{21}$ DeLong also reviewed the literature (ranging from 1930 to 2012) to understand the professional experiences of women library directors in academic libraries of the United States and Canada. ${ }^{22}$ It was discovered that, while women represented 75-80 percent of the library profession, their career advancement and leadership skills development were hindered by challenges such as career interruptions, domestic issues, lack of mobility, and lack of advanced studies. Therefore, although women academic librarians were found to be major contributors in top management roles within the profession, an adequate proportional representation in leadership was found to be lacking. To ensure their gender parity toward continued progress, women librarians should be motivated to become the future library directors/leaders. A critique on LIS leadership literature also emphasized that the experiences of women library leaders and administrators was poorly understood in the context of gender parity and the adoption of masculinized practices. ${ }^{23}$

The study of Akpebu Adjah and Van der Walt pointed out that significant hindrances to a woman's career progression included the following obstacles: societal expectations, family responsibilities, career conflicts, lack of involvement in research activities, inability to participate in continued professional development activities, lack of encouragement from employers to 
pursue further studies, and the "sense of having given up" and not being ambitious enough. The researchers recommended the development of career support systems for women to help them overcome these barriers. ${ }^{24} \mathrm{~A}$ recent study by Bladek reviewed the post-1974 literature on women's academic library leadership, which analyzed the challenges confronted by women in reaching leadership positions within their organizations. It was found that these were challenges associated with the gender stereotypes, leadership styles, career advancement, workforce issues, and lack of diversity among women library directors. ${ }^{25}$

\section{Attributes of Successful Women Library Leadership}

There is some evidence that women have openly written about their goals and their accomplishments, but the history of women's experiences regarding their career development and their achievements as leaders is not well documented. Epps identified the key attributes that appeared to have a greater impact on women becoming successful library leaders in ARL libraries. These attributes included being a facilitator, visionary, educator, and decision maker as well as being change focused, energetic, knowledgeable, self-confident, and flexible. ${ }^{26}$ Further, the attributes such as mobility, academic qualifications, service in professional organizations, and tenacity and perseverance were identified as being significant for a successful career and for the attainment of director-level jobs. ${ }^{27}$ McCracken described that higher education was compulsory for academic library leadership and found that 60 percent of the library director positions were occupied by women in liberal arts colleges. ${ }^{28}$ Martin investigated the positive effects of the transformational leadership styles on the professional lives of academic library directors, deans, and librarians and concluded that female library leaders also used the transformational leadership skills (individualized consideration, idealized influence, inspirational motivation, intellectual stimulation) in their roles as leaders. Similar to their male counterparts, they used these leadership styles to build relationships and create trust with coworkers, mentors, and others. ${ }^{29}$

\section{Community Services Offered by Women Library Leaders}

When a woman is appointed to a leadership position, she is in a challenging position where she has to opt for practices that "are contained within the paternalist state." ${ }^{30}$ Over the years, women librarians have gained recognition for the progressive role they have played in ensuring the provision of access to all the forms of information to their patrons in the current technological age. Blessing conducted a comprehensive study on the role of twenty-first-century female academic librarians in providing library services in academic libraries of River State, Nigeria. She found that female academic librarians possessed up-to-date professional skills and performed a veritable role in providing library services such as library advocacy, advisory services, community services, selective dissemination of information, current-awareness services, virtual reference services, and information literacy programs to their users. They were also found to be well equipped with the knowledge, competencies, and skills needed to play their significant roles in creating awareness about their library resources and services among users through varied marketing techniques. ${ }^{31}$ Similarly, Chidi-Kalu et al. reported that women librarians also acted as digital guides who identified their users' needs. ${ }^{32}$ They delivered the required library services via virtual and digital resources. ${ }^{33}$ Bin Hashim and Mokhtar opined that women librarians must commit themselves to research activities by writing, editing, reviewing research articles and books related to their profession and areas of interest. They also found that 
women librarians frequently engaged themselves in self-development programs and attended national and international conferences, online trainings, and webinars to expand their professional portfolios. ${ }^{34}$ Whitfield and Johnson explored the issue of women technology librarians as good citizens who faced the gendered nature of organizational citizenship behavior (OCB). They described that women technology librarians faced issues such as organizational injustices and gender stereotyping in the workplace. Their male coworkers performed "gatekeeping behavior," "sportsmanship behavior," and "reciprocate courtesy behaviors" by not giving them permission to use the technology they needed to perform their duties. These behaviors created a workplace culture fraught with such challenges that were difficult to overcome for the female librarians. They authors emphasized that the profession of librarianship needs to change its policies and practices, creating mechanisms that produce gender equality. ${ }^{35}$

\section{Women Library Leadership in Pakistani Context}

It is widely believed that there is a dearth of literature describing the efforts of women library leaders in the LIS profession in Pakistan. According to the HEC of Pakistan's website, there are 214 affiliated universities in Pakistan. ${ }^{36}$ Only 38 (out of these 214 university libraries) have a woman at the helm as the librarian in charge, chief librarian, library director, or head librarians, out of which 24 of the 131 public sector universities and 14 of the 83 private sector universities have women in a leadership position. These figures highlight the fact that women library leaders possess approximately 18 percent of the leadership positions in the LIS profession in Pakistan. Similarly, out of the 12 LIS schools/departments in Pakistan, only three have women working as the head of the academic department.

Trends toward education and research productivity of women librarians have been gradually increased in the country, and the profession is being continuously enriched by the efforts of women scholars. Jaswal and Sheikh highlighted the challenges of gender discrimination, unnecessary formalities, and lack of recognition among female librarians of Pakistan. ${ }^{37}$ The findings of a study conducted by Khan et al. also reported the various issues faced by women in LIS in Pakistan as: lack of capacity building, underrepresentation of the marginalized gender in institutional publications, lack of a gender-friendly environment in the library for staff and users, and a lack of privacy during information retrieval process. ${ }^{38}$ Ameen opined that the overall managerial/leadership issues of female librarians can be solved through continuous professional development activities. ${ }^{39} \mathrm{~A}$ study was conducted by Yousaf et al. investigating the job-related challenges of female librarians in a top-ranked university of Pakistan. The results revealed that, while librarianship is not considered to be a challenging profession, female librarians had fewer perks and privileges compared to their male colleagues. ${ }^{40}$ On the other hand, it was revealed by Farooq et al. that male librarians tended to possess higher levels of professional competencies compared to the female librarians. ${ }^{41}$ Khan and Tina Du found that women librarians relied on social media for personal and professional activities, which is least helpful for enhancing their technical skills. ${ }^{42}$ Factors such as privacy, parental years of schooling, marital status, and family support influenced acquisition of continuous professional development opportunities through social media. Generally, it was discovered that professional development opportunities were not freely accessible to women librarians in Pakistan. ${ }^{43}$

The genderwise analysis of the research productivity of Pakistani LIS authors confirms the domination of male LIS researchers in Pakistan. Out of 1,305 publications analyzed, 884 publications (68\%) were solely contributed by male authors and $196(15 \%)$ by female authors. 
It is worth mentioning that the first publication by a female author appeared in 1977, 30 years after Pakistan gained her independence as a country. ${ }^{44}$ Overall, as women are central to the well-being of any society, they also have a dominant position in the work force in the profession of librarianship. The above-cited literature, carried out in the perspective of advanced countries, mostly showcases a leadership journey fraught with multiple challenges for women librarians. Although they have many personal attributes that lend them to being great leaders, women librarians lack the opportunities essential for the development of their professional skills. There is also a dearth of literature on the role of women library leadership, especially in the context of Pakistan.

\section{Methodology}

A qualitative research approach was applied to thoroughly explore women library leadership in Pakistan. A self-developed, semistructured interview guide was prepared based on the reviewed literature and keeping in consideration the objectives of the study. The interview guide was finalized after a consultation with a panel of expert academicians and practitioners of the field. The experts suggested some changes in the interview guide that were subsequently incorporated in the final version. The interview guide is attached as appendix A. The population of the study comprised all women working in leadership positions in libraries and LIS departments in Pakistan. Twenty renowned senior women library leaders were purposefully selected to be included in the study. A country-level list was prepared of those participants who had worked or were working in a leadership position and had at least 15 years of professional experience as practitioners or academicians. In this regard, a consent letter containing objectives and significance of the study was emailed to the participants, and 16 participants showed their willingness to be included in the study (see table 1). Most of the interviews were conducted telephonically and were recorded with the permission of the participants, while some interviews were conducted at the offices of the participants. The average time of each interview was 40 minutes. Each interview was transcribed in a separate MS Word file and named P1 to P16. Two of the authors took part in the interview transcription process and verified the contents of the interview text to ensure the reliability of the data, while the other two authors were involved in the coding and data analysis process. The data analysis was performed using the Nvivo software version 12 (plus). All the interviews were coded separately with fictitious names as participant 1 to participant 16 (P1 to P16), and then these files were imported in the software. An open coding scheme was used, and all files were coded one by one. At first stage, the total 103 items (codes/nodes) were emerged from the data. In the next stage, four parent nodes were created (the parents' nodes were created considering the research questions of the study) and their relevant items were shifted/merged under their parent nodes. At the third stage, each item was carefully read and verified under their correct parent node. This process was repeated three times to ensure the validity and accuracy of the data. At the final stage, a total of 39 items emerged from the data. For example, the parent node in figure 1 is "women library leadership challenges" consisting of five child nodes (items).

\section{Data Analysis and Results}

\section{Demographic Information of Participants}

Table 1 shows the demographic information of the participants. All participants of the study were senior LIS professionals in Pakistan at the time of the study. These participants included 
five academicians and 11 practitioners: five belonging to public sector organizations and 11 working in private sector organizations in leadership positions. Most of the participants (n $=8$ ) had a master's degree in Library and Information Science, followed by six PhDs and two MPhils. Four academicians were PhDs and one academician had a master's degree. On the other hand, only two chief librarians had PhDs. This shows that the leaders in academic settings had a comparatively higher education than those who were practitioners of the subject. Most of the participants $(n=11)$ belonged to the Punjab province, while three were from Sindh, one from Baluchistan, and one from the capital territory of the country. The data shows that the Punjab province was the leader in gender equality and had the most women in library leadership positions. The professional experience of respondents ranged from 15 to 47 years, and they had been in their leadership position for a minimum of two to a maximum of 40 years.

\begin{tabular}{|c|c|c|c|c|c|c|}
\hline \multicolumn{7}{|c|}{$\begin{array}{c}\text { TABLE } 1 \\
\text { Demographic Information of the Participants }\end{array}$} \\
\hline $\begin{array}{l}\text { Participant } \\
\text { Code }\end{array}$ & Designation & Qualification & $\begin{array}{l}\text { University } \\
\text { Sector }\end{array}$ & Province & $\begin{array}{l}\text { Professional } \\
\text { and } \\
\text { Academic } \\
\text { Experience } \\
\text { (in years) }\end{array}$ & $\begin{array}{l}\text { Leadership } \\
\text { Experience } \\
\text { (in years) }\end{array}$ \\
\hline P1 & $\begin{array}{l}\text { Professor \& Ex- } \\
\text { Chairperson }\end{array}$ & $\begin{array}{l}\text { PhD, Post } \\
\text { Doc. }\end{array}$ & Public & Punjab & 35 & 13 \\
\hline P2 & $\begin{array}{l}\text { Professor \& } \\
\text { Chairperson }\end{array}$ & $\mathrm{PhD}$ & Public & Punjab & 25 & 14 \\
\hline P3 & $\begin{array}{l}\text { In charge of } \\
\text { department }\end{array}$ & $\mathrm{PhD}$ & Public & Baluchistan & 15 & 3 \\
\hline P4 & Chief Librarian & PhD & Public & Punjab & 23 & 23 \\
\hline P5 & $\begin{array}{l}\text { In charge of } \\
\text { department }\end{array}$ & PhD & Public & Sindh & 35 & 30 \\
\hline P6 & Chief Librarian & MLIS & Private & Sindh & 40 & 27 \\
\hline P7 & Chief Librarian & MPhil & Private & Punjab & 40 & 40 \\
\hline P8 & Chief Librarian & MLIS & Private & Punjab & 25 & 25 \\
\hline P9 & $\begin{array}{l}\text { Chief Librarian / } \\
\text { library director }\end{array}$ & MLIS & Public & $\begin{array}{l}\text { Islamabad } \\
\text { (Capital city) }\end{array}$ & 40 & 40 \\
\hline P10 & Chief Librarian & $\mathrm{PhD}$ & Public & Punjab & 22 & 22 \\
\hline P11 & Library Incharge & MPhil & Public & Punjab & 21 & 14 \\
\hline P12 & Department Head & MLIS & Public & Sindh & 47 & 40 \\
\hline P13 & Library Incharge & MLIS & Public & Punjab & 17 & 02 \\
\hline P14 & Chief Librarian & MLIS & Public & Punjab & 15 & 14 \\
\hline P15 & $\begin{array}{l}\text { Chief Librarian / } \\
\text { library director }\end{array}$ & MLIS & Private & Punjab & 20 & 10 \\
\hline P16 & Library Incharge & MLIS & Private & Punjab & 26 & 21 \\
\hline
\end{tabular}




\section{Findings}

RQ1: What Types of Challenges Are Being Faced by Pakistani Female Library Leaders in the Profession?

Data analysis revealed that female library leaders had to face multiple challenges throughout their professional careers. These include organizational challenges, widespread gender discrimination, professional identity as an issue, family responsibilities, and commitment issues (see figure 1). These are further discussed in detail to understand the scope and nature of these challenges.

\begin{tabular}{|c|c|c|}
\hline & FIGURE 1 \\
Women Library Leadership Challenges (From Left to Right) \\
Organizational \\
challenges
\end{tabular}

\section{Organizational Challenges}

Organizational challenges emerged as the biggest challenge that was being faced by women library leaders in Pakistan. These challenges were primarily the result of professional jealousy, favoritism, heavy workload within the organization, and fear of technology.

Some participants described that the organizational challenges were equally pervasive in both the public as well as private sector organizations. P11 declared, "When I switched the public to the private sector, and then again moved from the private to the public sector, I faced various issues due to the working environment and culture of these organizations." One participant (P13) disclosed that the nonavailability of proper platforms for women librarians' training and career development was a major hindrance to their success and prevented them from making effective professional contributions. The politics among the professional librarians and professionals' organizations have also adversely affected the career growth of young professionals and hostility among the LIS community. P12 highlighted the existence of resistance to change among professionals and organizations and stated, "Shifting from manual to automation, 
some certain challenges emerged. Resistance to change was a common reaction from those professionals who did not have the knowledge of computers, and feared for their jobs. Therefore, they became barriers against the technology. Even users of type writers were worried when computer emerged. Technological assistance was not proper. Change resistance was there."

\section{Gender Discrimination}

The data identified gender discrimination as the second most important challenge faced by women library leadership in Pakistan. Some of the participants stated that librarianship in Pakistan has long been dominated by men. The male employers also have stereotypical perceptions about female librarians; for example, it is commonly perceived that female librarians are unable to work on weekends and during evening hours, therefore not helpful during peak times of heavy workload in the library. One participant (P14) noted, "As far as the organization is concerned, there are some barriers because there is difficulty to digest females as leaders."

Some opined that the appointing authorities tended to assume men could perform their professional duties better than women. They are physically more fit and unencumbered by family issues and responsibilities, allowing them to have better overall performance in the workplace as compared to their female colleagues. Furthermore, as one respondent noted, women usually take a career break or leave the profession altogether after getting married. They also transfer from one city to another following their spouses' careers. These career gaps, unnecessary mobility, and job changes reflect badly on their curriculum vitae and can have a negative impact to their performance in the workplace (P11).

\section{Family Responsibilities}

Female library leaders perceived that amicably fulfilling their family responsibilities along with their job responsibilities was a major challenge for women leaders. Most of the participants claimed to have been involved in their children's upbringing and education throughout their careers. However, some of the respondents pointed out that they did not avail international opportunities due to their family commitments at home, and some indicated that their families placed restrictions on their work commitments and further education. As one respondent shared:

I must say all women face issues in their professions. Women have kitchen responsibilities; they are responsible for kids, while, on the other side, men do all these things without any such family responsibilities. You can better understand what I want to say. Women suffer due to health and overburden. Even if the husband is supportive, he cannot do anything for you; he cannot manage your kitchen or help with the kids and so on (P4).

Some of the respondents claimed that, due to their family concerns, they remained unable to gain national as well as international experience, as they felt they could not leave their children alone at home. Sometimes their loved ones were the cause of their not excelling in their chosen profession (P3, P7, P9, and P10).

\section{Professional Identity as an Issue}

Professional identity crisis also emerged as a key issue, as perceived by senior women library leaders. They perceived that society, faculty members, and even their coworkers consider 
librarianship an ordinary and clerical job. Librarianship appears to lack prestige in our society; librarians are not given their due respect. P10 stated, "The academician does not consider librarian as equal to them. The librarians have low status in academic organization. The academician thought that librarian is the clerical job. Moreover, society and relatives also have similar thinking." One participant highlighted that this identity crisis and thought process has resulted in their not getting their due recognition in the current knowledge landscape (P7).

\section{Commitment Issues}

Commitment issues from library professionals themselves were perceived as another big challenge by women library leaders. These leaders indicated that the evolution of technological revolution and the resistance to change attitude of library professionals presented a major challenge for the profession. The library professionals, especially the younger generation, should be motivated to accept this change and embrace their new roles in the new professional paradigm. One of the responders (P12) highlighted this viewpoint by stating, "Professionals do not get appropriate recognition in the general community due to their lack of technological knowledge. The professionals do not have a positive attitude. I do not find any appreciable dedication and commitment in the library professionals towards their changing role in the workplace."

\section{RQ2: What Are the Key Indicators of Their Success to Reach the Existing Leadership Posi-} tions?

The participants stated that the key indicators of their success in their jobs were effective use of technology, professional commitment, family support, international exposure, continued professional learning, and educational success (see figure 2).

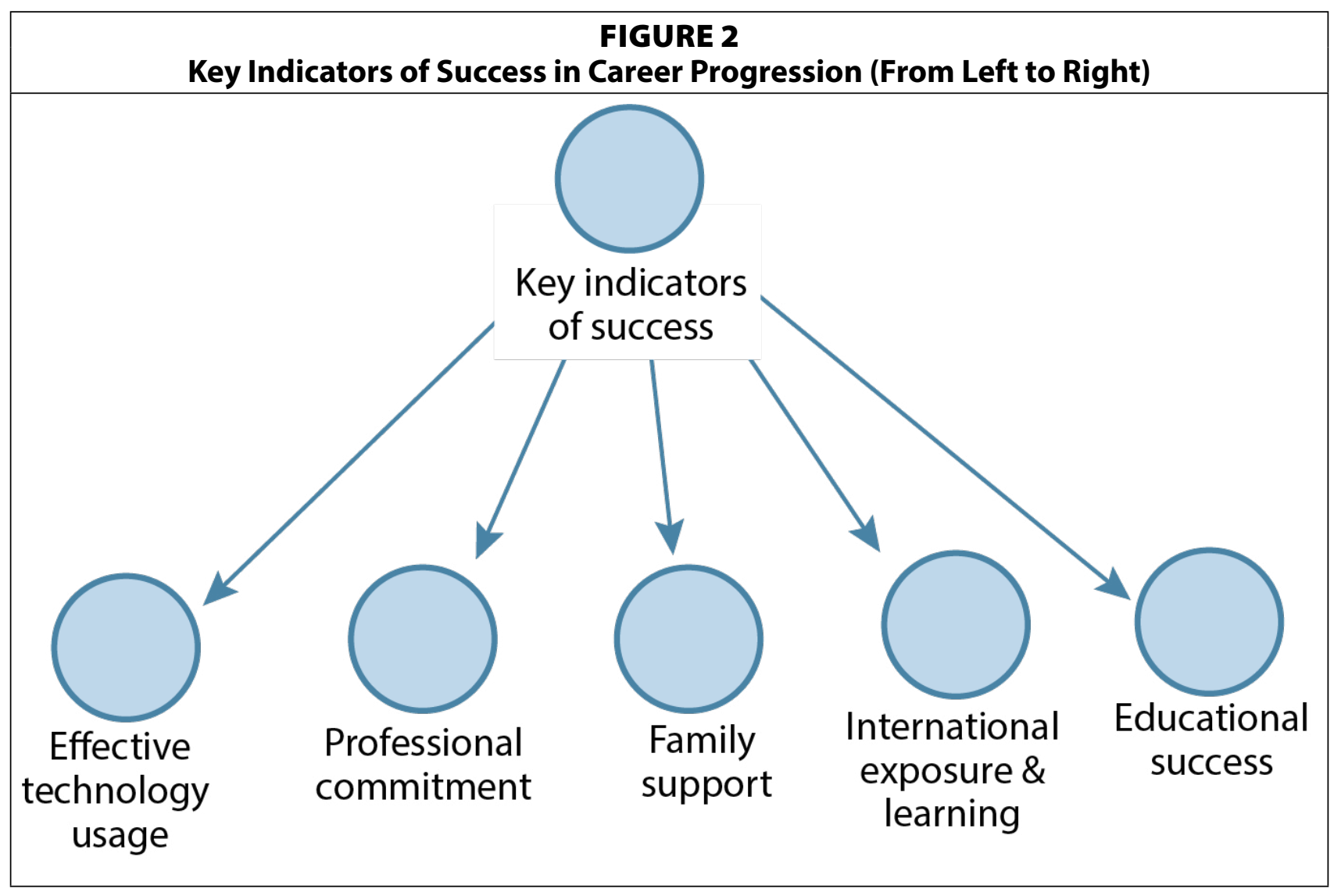




\section{Effective Technological Usage}

A majority of the participants (P1, P2, P3, P4, P5, P9, P13) considered the effective use of technology as the top indicator of success in their careers. They felt that it was due to the myriad blessings of modern technology that they were able to design new services, offer trainings and educational opportunities, and initiate digitization projects and documentation services in their respective organizations. Moreover, the participants also considered social media tools to be very helpful in engaging library users and marketing new services to them. One of the respondents shared this:

Technology always supported and facilitated us. Like in the current scenario, when the entire world is at home, we are supervising our students. Teaching them and guiding them. Due to technology, we are able to conduct digital transactions and engage in proper communication. The technology makes life easier (P5).

\section{Professional Commitment}

The commitment and professionalism of a woman leader appeared to be another key indicator of success. Ten women library leaders considered that their professionalism and high commitment to their profession was responsible for their continued success in their respective careers. The P1 stated, "This is not about the women and men, when you have a responsibility then you have to be focused, give your best to your assignment and keep your knowledge fresh. I teach and apply the rule of right man for the right job. I am not bound by any ideology, but I always appreciate good things, skills and consider merit in all aspects." In the same vein, another participant stated, "I learnt from my professional life that persistent effort can't be useless. If you are determined and focused, then you can achieve everything. You should be up to date in your professional life. You should race with the period."

\section{Family Support}

The results of the study highlighted family support to be another key indicator of success for women library leaders in Pakistan. Ten library leaders considered family support to be essential for excelling in a professional career in Library and Information Sciences. The interviewed women library leaders pointed out that their families supported higher education and academic careers and helped them achieve success in their chosen profession. One of the respondents (P1) said, "Before and after my marriage both of my families supported me, rather they facilitated me at all the stages of my academic career and higher education in all aspects. My family encourages me and gives me confidence."

\section{International Exposure}

A significant number of participants considered international exposure to be another key indicator of success. They considered it essential for becoming a part of the global network of library professionals and the learning opportunities such networks offer. Ten participants had international exposure from visiting various foreign countries for research paper presentations, higher education, training purposes, and as keynote speakers. P1 stated, "I visited more than 20 countries and have recently visited Japan for three months. This experience helps me to work collaboratively with experts from abroad." 
Three out of five academicians in the study had visited abroad primarily for the purpose of higher education or paper presentations. Additionally, 7 of the 11 chief librarians visited primarily for getting training as a part of an exchange program, as workshop participants, or for paper presentations.

\section{Educational Success}

Six of the study participants believed that getting higher education was instrumental in their big success. They felt that achieving higher education was a significant milestone in their career progression. They were promoted, produced significant publications, received best teacher awards, and achieved significant laurels as a result of their higher educational achievements. One of the respondents (P4) indicated: "My achievement is that I worked in diversified field; I was one of the first females to do MPhil in the country, and amongst the few females who have a foreign PhD."

RQ3: What Kinds of Community Services Are Being Offered by Women Library Leaders? It was found that the community services being offered by women library leaders were capacity building for researchers, students, staff, and other library professionals; organization of national and international professional conferences; actively working on research journals in various capacities (like editor, editorial member, reviewer, secretary); and arranging welfare and philanthropic activities (see figure 3).

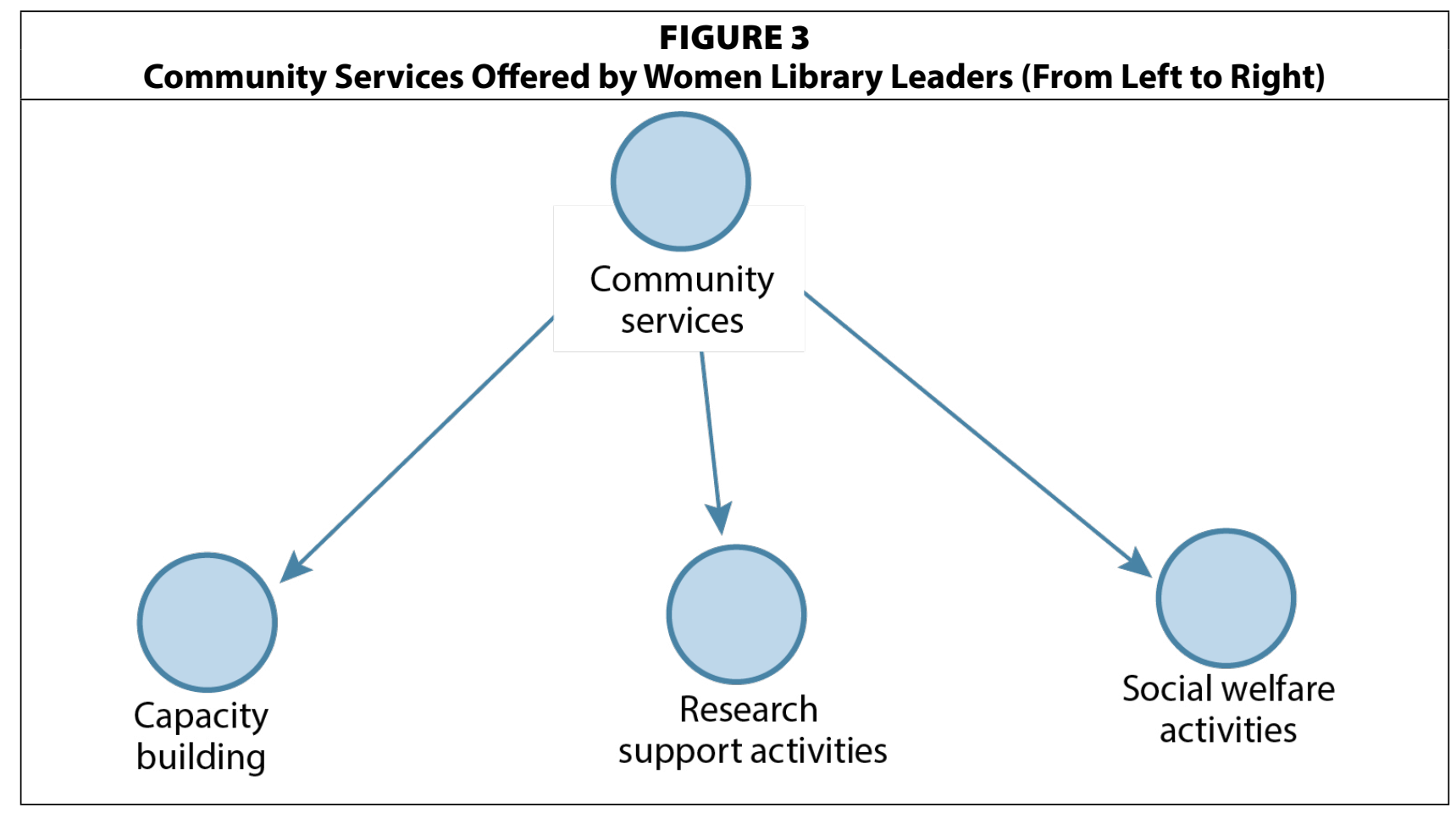

\section{Capacity Building}

Majority of the respondents were found to be engaged in capacity-building activities for their various stakeholders including researchers, students, coworkers, subordinates, and other library professionals. This emerged as a major contribution being made by these women library leaders. Some of these leaders were also involved in organizing international and national professional conferences in their organizations, creating training opportunities and 
providing a platform for collaborative learning and ideas sharing. As P1 said, "At the time of departmental 100 years celebrations, I organized the international conference and set a standard in Pakistan and published its proceedings in well-organized national journal."

\section{Research Support Activities}

The participants highlighted their work in various research journals of national and international repute. They worked in these journals in varied capacities; some of the senior participants were prolific contributors in various research journals, while others were responsible for reviving local professional research journals. Some claimed to have envisioned and started professional magazines, while others contributed by working as reviewers or in an administrative capacity. One respondent (P1) stated, "I have revived the departmental journal. In 2004, I started as assistant editor for the departmental magazine. Within few years I converted this student journal into a well reputed Pakistani journal in the field of LIS. Later on, I performed chief editor responsibilities for this journal (2005-2009)."

\section{Welfare and Philanthropic Activities}

Most of the participants were actively involved in social welfare activities and had many philanthropic accomplishments; however, they did not share any detail in this regard. Some participants shared minimum details of such activities, as P6 stated:

Being member of LIONS club and Sun Rise Club, I have visited villages to train students for teaching. We also provide funding for home and convert small home into bricks homes. We also constructed bathrooms in different areas of Karachi city.

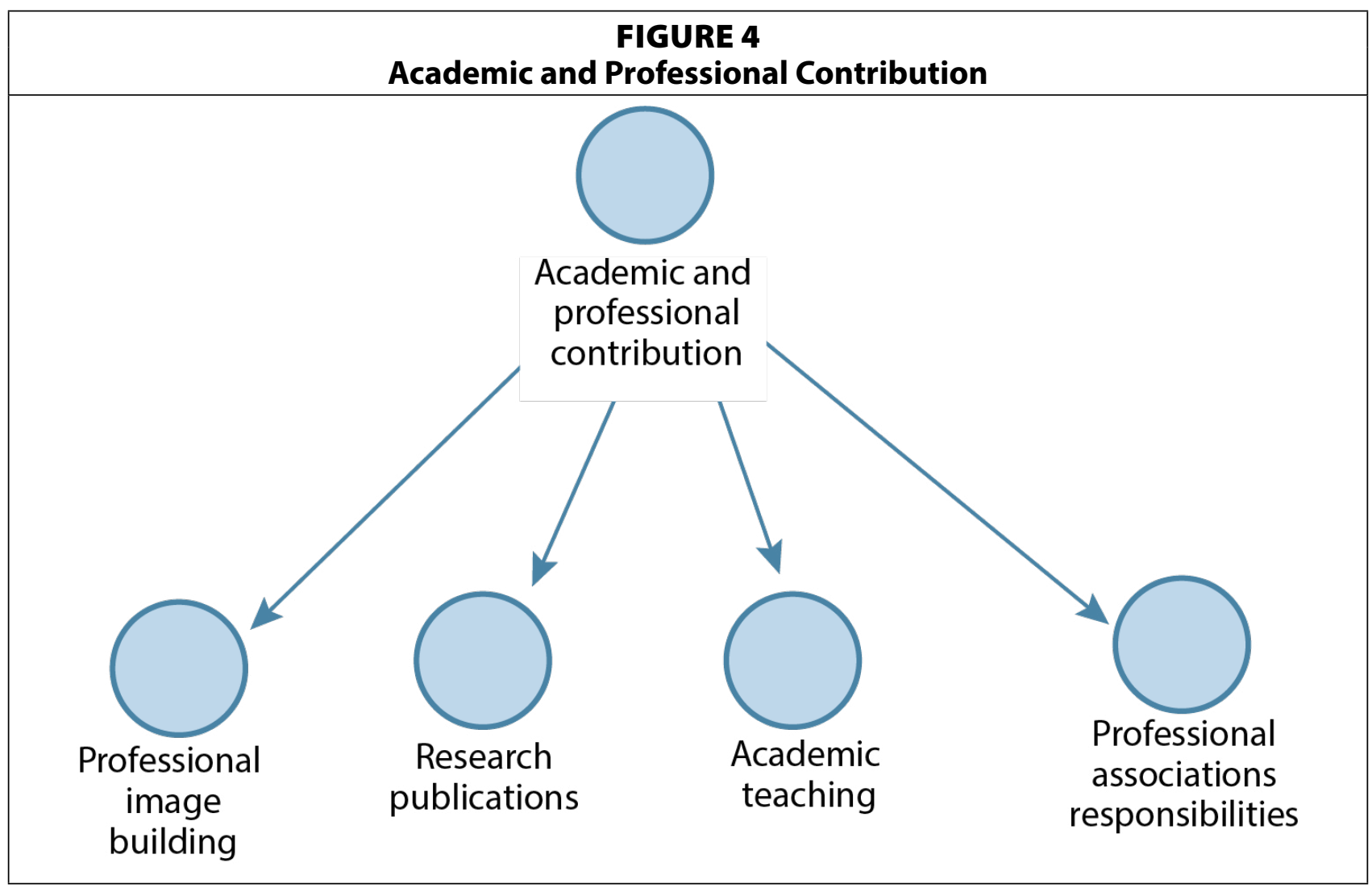


RQ4: What Are the Academic and Professional Contributions of Pakistani Women Library Leaders?

The participants discussed about their professional and academic contributions. These included professional image building, publishing research in national and international journals, teaching responsibilities, and professional association's responsibilities in different capacities (Figure 4).

\section{Professional Image Building}

Professional image building has emerged as a top contribution from women library leaders of Pakistan. Most of the participants highlighted their efforts in building a positive image of librarianship by trying to develop and offer innovative services in libraries, collaborating with members of various university and national committees, and supervising Higher Education Commission approved PhD students. Following are the thoughts of one of the women leaders interviewed (P1):

I have chaired the university Doctoral Coordination Committee, worked for the development of LIS department and established its identity in the university as well as in the society. I focused on the capacity building of the faculty. Now all faculty members have their PhD degrees. I served as member of various organizing committees and acted as a referee for the A-LIEP 2006 Conference in Singapore; A-LIEP Conference 2011 in Malaysia and Indian Library Association Platinum Jubilee International Conference in Mumbai Nov 2008. I have produced 12 PhDs in Pakistan and 8 more are in the completion process.

\section{Research Publications}

Some of the library women leaders had numerous research publications in national and international journals (see table 2). Some of these publications were in impact factor journals while others were in national and international journals of good repute. Some respondents, however, claimed that this activity belonged to the academicians and as practicing librarians they had not devoted much time to research and publishing during their professional careers. The data searched (see table 2) in Library and Information Science Abstracts (LISA) and Library Information Science \& Technology Abstracts (LISTA) showed that, out of the 16 participants of the study, only four had more than 10 publications, and only two had published in more than 100 publications in the course of their careers. It is notable that those female participants who had more than 100 publication credits were academicians. It is an alarming finding that, even though all of the participants had been working in universities, a majority of them $(\mathrm{n}=$ 8) had not contributed a single research publication during their career. Out of the eight nonpublished participants, seven held a master's degree in LIS and one had an MPhil degree. This finding highlights the importance of higher education while engaging in research activities.

\section{Teaching Experience}

Five of the participants had been formally working as teachers in their universities (see table 1). Others either had teaching engagements as visiting faculty or were involved in teaching practical short courses at various universities. Some of the participants had experienced both aspects of their profession that is professional librarianship and professional teaching. 


\begin{tabular}{|l|c|l|l|l|}
\hline \multicolumn{7}{|c|}{ TABLE 2 } \\
\hline $\begin{array}{l}\text { Participant } \\
\text { Code }\end{array}$ & $\begin{array}{l}\text { Total } \\
\text { Publication }\end{array}$ & Designation & Qualification & $\begin{array}{l}\text { University } \\
\text { Sector }\end{array}$ \\
\hline P1 & 106 & Professor \& Ex-Chairperson & PhD, Post Doc. & Public \\
\hline P2 & 105 & Professor \& Chairperson & PhD & Public \\
\hline P3 & 16 & Incharge of department & PhD & Public \\
\hline P4 & 17 & Chief Librarian & PhD & Public \\
\hline P5 & 5 & Incharge of department & PhD & Public \\
\hline P6 & 5 & Chief Librarian & MLIS & Private \\
\hline P7 & 2 & Chief Librarian & MPhil & Private \\
\hline P8 & 0 & Chief Librarian & MLIS & Private \\
\hline P9 & 0 & Chief Librarian / library director & MLIS & Public \\
\hline P10 & 3 & Chief Librarian & PhD & Public \\
\hline P11 & 0 & Library Incharge & MPhil & Public \\
\hline P12 & 0 & Department Head & MLIS & Public \\
\hline P13 & 0 & Library Incharge & MLIS & Public \\
\hline P14 & 0 & Library Incharge & MLIS & Public \\
\hline P15 & 0 & Chief Librarian / library director & MLIS & Private \\
\hline P16 & 0 & Library Incharge & MLIS & Private \\
\hline
\end{tabular}

P4 stated: "Currently, I am a chief librarian; however, I have also worked as a Senior Lecturer at the University of Malay, Malaysia. As I had to come back to Pakistan, so I did not sign a further contract. Again, I taught in PU as visiting faculty." Another participant (P10) related this: "I taught two semesters at PU. The subject was human resources and science resources." Similarly, P11 shared, "I am teaching at AIOU since 2012. I am teaching research and communication studies and cataloguing." Likewise, P7 said, "I teach digitization and digital library at PU as visiting lecturer. Before this, I taught at Agriculture Research Council for short trainings and course."

\section{Professional Associations Responsibilities}

All of the participants were asked about their involvement with various professional library associations. It has been observed that only five female library leaders have played or are playing key roles in national and international professional associations, while the rest of the participants were not actively involved in any such associations. P7 highlighted her extensive contributions in this regard: "My professional contribution is to establish the PLA computer training center. It was a very successful project. Many professionals requested me to give them special training about computers because they were very hesitant to even switch on a computer and use this new technology." Similarly, P1 said, "In 2007, during the PLA conference, I acted as an academic facilitator. I had to call for papers, arrange and manage them for the conference. I was also the member of PLA continuing education committee. For the revival of PLA in 2007, I encouraged the students who then actively participated in the revival movement."

\section{Discussion}

The study aimed to explore the women library leadership in Pakistan. It investigated the major 
challenges faced by women, key indicators of their success, as well as the community services rendered and professional contributions made by women leaders in their journey of career progression. The findings are discussed according to the objectives of the study as follows:

Organizational challenges, gender discrimination, family responsibilities, professional identity crisis, and commitment issues were the top challenges being faced by Pakistani women library leaders. Librarianship has always been considered to be a female-oriented profession; however, there have been disproportionately low number of females in the leadership position till recent times. ${ }^{45}$ It is only now that women have risen in the ranks and hold a number of leadership positions in developed countries. ${ }^{46}$ However, this scenario is different in developing countries where men still hold most of the leadership positions. ${ }^{47}$ The women academic library leaders in Pakistan possess approximately 18 percent of the leadership positions. One of the biggest issues for women library professionals is to carry the job along with fulfilling family responsibilities, doing domestic work and looking after the children as well. Additionally, if they transfer to other cities, they prefer to quit the job instead of joining there. The young women library professionals are also hesitant to join the job other than their residence even if they are agreeing to work in lower scale and low wages in their native cities. Consequently, women still face several challenges in their quest for the coveted leadership position as well as in maintaining it. The top challenge in this regard was found to be overcoming the "organizational challenges" associated with professional jealousy, favoritism, heavy workload within organization, and fear of technology among professionals. The women library leaders described that professional jealousy and favoritism were the key issues for women's underrepresentation in top leadership. Other factors hindering the women librarians' career progression include the various family responsibilities that the women need to fulfill, and the pervasive gender discrimination in the workplace as well in society. ${ }^{48}$ Difficulties in handling the equally important dual responsibilities of family and the workplace can force women librarians to give up their ambitions and engenders a "sense of having given up" on their careers. ${ }^{49}$ Epps found that the minority African American library women required the same set of nonminority library skills, but they required additional attributes to overcome stereotypes in the work environment..$^{50}$ Similarly, in the male-dominant professional environment in developing countries, there is a need to have favorable policies at the organizational and national level to protect the rights of working women. Women should be treated equally to their male colleagues based on merit, skills, and experience.

The results of the study also link career success to the early adoption and effective use of technology. The average professional experience of each participant was almost 28 years (see table 1). Some participants were pioneers of the profession or in their respective institutions who started technological courses and automation in their libraries in Pakistan. Understandably, the adoption of technology has played a vital role in the career progression of the participants. Ashiq, Rehman, and Batool have also highlighted the importance of early technological adoption among library leaders in addressing the emerging challenges. ${ }^{51}$ They argued that there is a need to introduce compatible smart services to attract the modern library users. ${ }^{52}$ Development and implementation of such services are not only helpful for these future leaders' career progression, but they are also necessary for the survival of the profession. Professional commitment, family support, international exposure and learning, and educational success were also identified as key indicators in career progression for women library professionals in developing countries. Professional commitment and family support help the women librarians 
to manage their careers effectively and still keep a work-life balance. Their committed attitude also motivates them to search for better opportunities and plan their careers for the future. This finding is contrary to the results of Akpebu Adjah and Van der Walt, who reported that multiple challenges led them to give up and lose all ambition for career progression, thus causing women librarians to end up staying in the same job for a long time. ${ }^{53}$

Most of the women library leaders were found to be involved in capacity-building activities and in organizing national and international professional conferences, training opportunities and providing a platform for collaborative learning and idea sharing. Moreover, the participants indicated that attending national and international conferences, online trainings and webinars was an excellent way to get novel ideas and expand one's potential capabilities. ${ }^{54}$

The Global Economy data also indicated that Pakistan has ranked low in respect of female labor force participation at the international and continental level. The female labor force ranking list of 2019 showed that Pakistan ranked 171th among 182 countries and ranked 38th among 46 Asian countries. ${ }^{54}$ It is therefore imperative that the librarianship profession in Pakistan engage in female-focused policy making and created learning and training opportunities for women to boost recruitment of females into the profession..$^{55}$ Such policy-making and training opportunities will not only motivate and encourage female library professionals to enter the profession, but also guide them to excel in it. They will also equip them with skills needed to overcome the challenges that they may face in their career progression and groom them for future leadership positions.

It was found that women library leaders in Pakistan have made many valuable professional and academic contributions during the course of their careers. These include their untiring efforts to build the image of librarianship as a respected profession, their research activities and publications in renowned journals, their teaching responsibilities, as well as their involvement in professional association activities in varied capacities, among others. In short, these women library leaders have been some of the pioneers of modern librarianship in Pakistan, with some possessing more than 30 years of professional or leadership experience (see table 1). The publication data of the participants, however, did reveal a very alarming scenario. It was revealed that a majority of the participants $(n=8)$ had not produced a single research publication during their tenure as a librarian. The authors considered it very disconcerting that most of the participants were not involved in any form of research productivity even though they were working in university libraries. A recent study by Siddique, Rehman, Khan, and Altaf also confirmed the higher research productivity of male researchers in Pakistan when they analyzed the genderwise research productivity of Pakistani LIS authors in a recent study..$^{56}$ Out of a total of 1,305 publications, 884 publications (68\%) were contributed by male authors and $196(15 \%)$ by female authors. A total of $225(17 \%)$ had been contributed jointly by male and female authors. The first publication by a female author appeared 30 years after the independence of Pakistan in 1977. Moreover, the analysis of the top-20 most productive Pakistani authors indicated that only six were females and all of them were academicians. It has long been considered that a researcher can better understand the needs of other researchers. Therefore, a library leader with a research background is more suited for developing appropriate research support services for other researchers in a university. It is suggested that policy makers, HEC, and individual employers should include the need for a set number of research publications in their recruitment criteria for the position of a chief librarian of any university. Moreover, it has been noted that a majority of women have a 
limited role in professional LIS associations and that they avoid taking on responsibilities related to these professional associations. It could be due to the male dominant LIS culture in the country where most of the prominent and important positions within the profession and professional associations are held by men. LIS professional associations should devise a fair election procedure for top leadership positions, and some seats should be reserved for women nominations in professional associations. The provision of equal opportunity will encourage women to come forward and play their role in the associations and contribute toward the continuous professional development of other working female librarians.

In this regard, it is imperative to launch equal opportunity and gender equality awareness campaigns at the national level to encourage men to not only support women in the workplace but also support the women in their lives in shouldering their family responsibilities and encouraging them to pursue their career goals. Such policies and awareness campaign will help to recruit skillful and professional women into the main decision-making and leadership positions.

\section{Limitation and Future Research Direction}

The study was limited to the perceptions of academic woman library leaders working in the university sector only. The study is further limited to its sample size, as only 16 senior women library leaders took part in the study, and most of them belonged to the Punjab province of Pakistan.

Future research should be conducted by using a quantitative and mixed-method approach to cross-validate the findings. In addition, a qualitative study is further required to investigate the factors, reasons, and issues behind the alarming lack of women in leadership positions in Pakistan, as less than 18 percent of the top LIS positions are held by Pakistani women. Future research should focus on perceptions of library leaders working in other sectors such as college, public, and special libraries, as well as the national library.

\section{Implications of the Study}

This is the first in-depth qualitative investigation carried out on women library leadership in Pakistan. The results of the study suggest the following implications for the society, policy makers, and top management of universities. These can guide them to attract, retain, and promote competent women library leaders in the future.

\section{Theoretical Implications}

Female academic library leadership is an important area of research; there is a lack of literature, and this topic has been severely neglected in Pakistan. The current research is an attempt to bridge the gap and addresses the professional, academic, and community contributions of Pakistani women academic library leaders.

\section{Social Implications}

An awareness campaign in Pakistani society should be launched to highlight the importance of female leadership role in LIS. All stockholders of the society including families (parents, husband, and children), employers, colleagues, women's organizations, relevant associations, and communities should be educated to facilitate, motivate, and encourage the females working in leadership positions. Family members should share the domestic responsibilities. 
The society should encourage, motivate, and invest in higher education of women. Barriers such as organizational challenges, gender inequality, family responsibilities (early marriage, childcare, and domestic responsibilities), and lack of professional identity should be removed. They should discourage the belief that men are leaders and that a woman's place is only in the household. Female library leaders should also make efforts to maintain good working relationships and strategic alliances with their male colleagues who are often the leaders and gatekeepers in the profession, to achieve further progress within the organization. The role of professional associations and LIS schools is very crucial to initiating awareness campaigns and making alliance with government and nongovernmental organizations (NGOs). Besides, this alliance can help highlight the current situation of women library professionals and work for equal opportunities, environment, and wages.

\section{Practical Implications}

The findings of this study highlight organizational, familial, and gender discrimination as some major barriers. The organization and top management should provide them with equal opportunities and effective participation in all kinds of leadership positions in academic, special, public, and national libraries. Additionally, LIS women should enhance their leadership skills and engage in social networking to fill the gaps in their competencies. Professional library associations should play a key leadership role and engage them in associations. They should provide equal and fair opportunities to women for various continuing professional development activities, as well as mentorship activities focusing on imparting knowledge, tools, and skills required to effectively manage leadership positions. Library and information science schools should redesign their curricula and continuously update them to prepare female students to acquire the skills essential for overcoming future professional and leadership challenges. The findings of this study are helpful for university administrations in hiring and capacity building of women librarians based on required leadership skills. Furthermore, it will be useful for mid-career-level female librarians in their career planning and progression toward future leadership positions. In addition, there is a need to recruit and promote talented women library professionals into the LIS profession who are professionally committed and provide an innovative and visionary leadership.

\section{Implications for Policy Makers}

The findings of the study highlight that policy making is a highly neglected area in the library profession in Pakistan, especially the policy areas focusing on women work force participation. The HEC Pakistan, Punjab Higher Education Commission, and the administrations of the universities should develop and implement such policies and standards for women workforce development that can be practiced in the true letter and spirit by universities, professionals, library schools, and professional library associations. The relevant authorities can also take the initiative to require a minimum number of research publications from their applicants for leadership positions, to improve the research skills, equal opportunities, and fair selection process for the applicants. This requires involvement of key stakeholders, especially the library schools and library associations. The relevant authorities, especially HEC Pakistan, Punjab HEC, administration of the universities, and practitioners need to capitalize on the high-level momentum regarding woman empowerment, women's rights, and leadership in the country, and ensure more equitable gender relations in the profession. 


\section{Conclusion}

Academic women library leadership is often neglected area in Pakistan. While some research studies had been conducted on women librarianship in Pakistan, none of them had addressed female library leadership. This study is an attempt to fill the gap on female library leadership in literature. The results of the study highlight the major challenges faced by women library leaders, key indicators of their success, as well as their community services and professional contributions nationally and internationally. It is very thought-provoking that women possess less than 18 percent of the total LIS leadership jobs in Pakistan. The most frequent challenges being faced by Pakistani women library leaders were perceived to be organizational challenges, gender discrimination, working women's family responsibilities, professional identity crisis and lack of professional commitment. The key indicators of their success in leadership positions were effective use of technology, professional commitment, family support, international exposure, and continuous learning. The findings also highlight their considerable professional and academic contributions in being involved in professional image building, publishing research, teaching, and playing an active role in professional associations. It is encouraging that they also perform other services such as capacity building, organizing conferences, editorial roles in research journals, and social welfare activities. Despite this, it is alarming to note that more than half of the participants were not practically involved in research activities and produced no publications during their careers. Pakistani libraries need more women leaders to be nurtured and included in the succession planning for the future. They should also be more involved in research activities. Every female librarian should be mentored, encouraged, and motivated to work up to her full potential, thus ensuring that the university employers are able to find capable women library leaders in the near future. The greater the diversity, the more successful will be the organization. The understanding of career advancement as well as professional and academic contributions for women library leaders will also help and inspire more women librarians to take on leadership positions in the future. Besides the role of professional library associations, LIS schools, employer organizations, and government and NGOs, it is very crucial that Pakistani women library professionals should target the leadership positions and equip themselves with the required attributes, knowledge, expertise, and skills. As the current female library professionals are preparing for their future leadership roles, the finding of the study will guide and motivate them to reach their full potential. 


\section{APPENDIX A. Instrument / Interview Guide} Demographic information:

Name of university (public or private):

Designation:

Highest degree:

Province:

Overall Experience (in years):

Experience on leadership position (in years):

\begin{tabular}{|l|l|}
\hline Research questions & Probing questions \\
\hline $\begin{array}{l}\text { What types of barriers are being faced } \\
\text { by Pakistani female library leaders in the } \\
\text { profession? }\end{array}$ & $\begin{array}{l}\text { - Sociological barriers } \\
\text { - Professional barriers } \\
\text { - Organization barriers } \\
\text { - Domestic / family barriers } \\
\text { - Any other barriers? }\end{array}$ \\
\hline $\begin{array}{l}\text { What are the key indicators of their success } \\
\text { to reach their existing leadership positions? }\end{array}$ & $\begin{array}{l}\text { - Role of Innovative technology in their success } \\
\text { - Key achievement in the carrier }\end{array}$ \\
\hline $\begin{array}{l}\text { What kinds of community services are being } \\
\text { offered by women library leaders? }\end{array}$ & $\begin{array}{l}\text { - Awards/scholarship } \\
\text { - Any other indicator? }\end{array}$ \\
\hline $\begin{array}{l}\text { What is the academic and professional } \\
\text { contribution of Pakistan women library } \\
\text { leaders? }\end{array}$ & $\begin{array}{l}\text { - Training for library users / scholars / faculty ... } \\
\text { - Voluntarily working other than librarianship }\end{array}$ \\
& - Any other services? \\
\hline
\end{tabular}

Concluding remarks:

\section{Notes}

1. Janice Clinedinst Fennell, A Career Profile of Women Directors of the Largest Academic Libraries in the United States: An Analysis and Description of Determinants (Tallahassee, FL: Florida State University, 1978); Roma M. Harris, Librarianship: The Erosion of a Woman's Profession (New York, NY: Ablex Publishing Corporation, 1992); Marta Deyrup, "Academic Library Leadership, Second Wave Feminism, and Twenty-First Century Humanism," Leadership in Academic Libraries Today: Connecting Theory to Practice 91 (2014): 91-141.

2. Deyrup, "Academic Library Leadership, Second Wave Feminism, and Twenty-First Century Humanism," 91-141.

3. Fennell, A Career Profile of Women Directors of the Largest Academic Libraries in the United States.

4. Anita R. Schiller, "Women in Librarianship," Advances in librarianship 4 (1974): 103-47.

5. Kathleen DeLong, "Career Advancement and Writing about Women Librarians: A Literature Review," Evidence Based Library and Information Practice 8, no. 1 (2013): 59-75.

6. Barbara B. Moran, Elisabeth Leonard, and Jessica Zellers, “Women Administrators in Academic Libraries: 
Three Decades of Change," Library Trends 58, no. 2 (2009): 215-28. 91-141.

7. Deyrup, "Academic Library Leadership, Second Wave Feminism, and Twenty-First Century Humanism,"

8. Claudette Shackelford McLinn, "An Analysis of the Two African-American Women Presidents of the American Library Association: Demographics, Leadership Duties and Responsibilities, Leadership Styles, and Leadership Pathways" (PhD diss., Pepperdine University, 2006).

9. Maurice B. Wheeler, "Averting a Crisis: Developing African American Librarians as Leaders," Handbook of Black Librarianship (Lanham, MD: Scarecrow Press, 2000): 169-82.

10. Sharon K. Epps, "African American Women Leaders in Academic Research Libraries," portal: Libraries and the Academy 8, no. 3 (2008): 255-72.

11. $\mathrm{mc}$, "Female labor force participation: country rankings; The Global Economy, business and economic data of 200 countries," https://www.theglobaleconomy.com/rankings/Female_labor_force_participation/ [accessed March 22, 2020].

12. Olive Akpebu Adjah and Thomas Van der Walt, "Career Progression of Female Librarians in Public University Libraries in Ghana," Journal of Librarianship and Information Science 51, no. 2 (2019): 331-45; Murtaza Ashiq, Shafiq Ur Rehman, and Syeda Hina Batool, "Academic Library Leaders' Challenges, Difficulties and Skills: An Analysis of Common Experiences," Libri 68, no. 4 (2018): 301-13; Murtaza Ashiq, Shafiq Ur Rehman, and Syeda Hina Batool, "Academic Library Leaders' Conceptions of Library Leadership in Pakistan," Malaysian Journal of Library E Information Science 24, no. 2 (2019): 55-71; Muhammad Umar Farooq et al., "Current and Required Competencies of University Librarians in Pakistan," Library Management 37, no. 8/9 (2016): 410-25.

13. Higher Education Commission, Pakistan, "HEC Recognized Universities and Degree Awarding Institutions," https://hec.gov.pk/english/universities/pages/recognised.aspx [accessed April 28, 2020].

14. Farooq et al., "Current and Required Competencies of University Librarians in Pakistan," 410-25.

15. Arif Khan et al., "Gender Mainstreaming in Pakistani Libraries: Analysing The Possibilities," Journal of Librarianship and Information Science 49, no. 1 (2017): 107-14.

16. Janice J. Kirkland, “The Missing Women Library Directors: Deprivation versus Mentoring," College $\mathcal{E}$ Research Libraries 58, no. 4 (1997): 375-83; DeLong, "Career Advancement and Writing about Women Librarians," 59-75; E. Blessing and E. Mercy, "The Role of the 21st Century Female Librarian for Service Delivery in Nigeria: Case Study of Academic Libraries in Rivers State," Journal of Library and Information Sciences 7, no. 1 (2019): 106-16.

17. Akpebu Adjah and Van der Walt, "Career Progression of Female Librarians in Public University Libraries in Ghana," 331-45.

18. Joseph Stokes, Stephanie Riger, and Megan Sullivan, "Measuring Perceptions of the Working Environment for Women in Corporate Settings," Psychology of Women Quarterly 19, no. 4 (1995): 533-49.

19. L. Chapman, "From Here to Fraternity: Interviews and Cold Porridge," UC and R Newsletter 35 (1991).

20. Miriam Y. Holden, "The Status of Women Librarians," Antiquarian Bookman 36 (1965): 647-48.

21. Moran, Leonard, and Zellers, "Women Administrators in Academic Libraries," 215-28.

22. DeLong, "Career Advancement and Writing about Women Librarians," 59-75.

23. Christine Neigel, "LIS Leadership and Leadership Education: A Matter of Gender," Journal of Library Administration 55, no. 7 (2015): 521-34.

24. Akpebu Adjah and Van der Walt, "Career Progression of Female Librarians in Public University Libraries in Ghana," 331-45.

25. Marta Bladek, "From Women-Staffed to Women-Led: Gender and Leadership in Academic Libraries, 1974-2018," Journal of Library Administration 59, no. 5 (2019): 512-31.

26. Epps, "African American Women Leaders in Academic Research Libraries," 255-72.

27. Kirkland, "The Missing Women Library Directors: Deprivation versus Mentoring," 375-83.

28. Peter McCracken, "The Presence of the Doctorate among Small College Library Directors," College $\mathcal{E}$ Research Libraries 61, no. 5 (2000): 400-08.

29. Jason Martin, "Personal Relationships and Professional Results: The Positive Impact of Transformational Leaders on Academic Librarians," Journal of Academic Librarianship 43, no. 2 (2017): 108-15.

30. Jill Blackmore, "Social Justice and the Study and Practice of Leadership in Education: A Feminist History," Journal of Educational Administration and History 38, no. 2 (2006): 185-200.

31. Blessing and Mercy, "The Role of the 21st Century Female Librarian for Service Delivery in Nigeria: Case Study of Academic Libraries in Rivers State," Journal of Library and Information Sciences 7, no. 1 (2019): 106-16.

32. E. Chidi-Kalu, N. Abdulrahim, and F. Adepoju, "The Role of Women Librarian in Information Literacy in the 21st Century: A Conceptual Perspective," Journal of Association of Women Librarians in Nigeria 1, no. 2 (2018): $127-40$. 
33. Salman Haider, "Library \& Information Technology," Librarianship Studies and Information Technology (2016), https://www.librarianshipstudies.com/p/technology.html.

34. Laila Bin Hashim and Wan Mokhtar, "Preparing New Era Librarians and Information Professionals: Trends and Issues," International Journal of Humanities and Social Science 2, no. 7 (2012): 151-55.

35. Sharon Whitfield and Ane Turner Johnson, "Women Technology Librarians as Good Citizens," Journal of Academic Librarianship 45, no. 5 (2019).

36. Higher Education Commission, Pakistan, "HEC Recognized Universities and Degree Awarding Institutions."

37. Qasira Jaswal and Javed Anujum Sheikh, "Building Strategic Vision for Invisible Librarian: A Case Study of Female Librarian" (paper presented at PLA International Conference, Islamabad, Pakistan, 2010).

38. Arif Khan and Jia Tina Du, "Professional Development through Social Media Applications: A Study of Female Librarians in Pakistan," Information and Learning Science (2017).

39. Kanwal Ameen, "Challenges of Preparing LIS Professionals for Leadership Roles in Pakistan," Journal of Education for Library and Information Science (2006): 200-17.

40. Ammara Yousaf, Madiha Tariq, and Muhammad Shahid, "Management Issues for Female Librarians: A Case Study of University of the Punjab," Library Philosophy \& Practice (2013).

41. Farooq et al., "Current and Required Competencies of University Librarians in Pakistan," 410-25.

42. Khan and Tina Du, "Professional Development through Social Media Applications."

43. Arif Khan and Muhammad Rafiq, "Designing Effective In-Service Training for Librarians in Pakistan," $L i-$ brary Philosophy and Practice (e-journal) (2013).

44. Nadeem Siddique et al., "Library and Information Science Research in Pakistan: A Bibliometric Analysis, 1957-2018," Journal of Librarianship and Information Science (2020).

45. Fennell, A Career Profile of Women Directors of the Largest Academic Libraries in the United States; Harris, Librarianship: The Erosion of a Woman's Profession; Deyrup, "Academic Library Leadership, Second Wave Feminism, and Twenty-First Century Humanism," 91-141.

46. Moran, Leonard, and Zellers, "Women Administrators in Academic Libraries," 215-28.

47. Ashiq, Ur Rehman, and Hina Batool, "Academic Library Leaders' Challenges, Difficulties and Skills," 301-13; Ashiq, Ur Rehman, and Hina Batool, "Academic Library Leaders' Conceptions of Library Leadership in Pakistan"; M. Ashiq, Shafiq Ur Rehman, and G. Mujtaba, "Future Challenges and Emerging Role of Academic Libraries in Pakistan: A Phenomenology Approach," Information Development (2020): 1-16.

48. Bladek, "From Women-Staffed to Women-Led," 512-31; Khan et al., "Gender Mainstreaming in Pakistani Libraries," 107-14.

49. Akpebu Adjah and Van der Walt, "Career Progression of Female Librarians in Public University Libraries in Ghana."

50. Epps, "African American Women Leaders in Academic Research Libraries," 255-72.

51. Ashiq, Ur Rehman, and Hina Batool, "Academic Library Leaders' Challenges, Difficulties and Skills."

52. Ashiq, Ur Rehman, and Mujtaba, "Future Challenges and Emerging Role of Academic Libraries in Pakistan," 1-16.

53. Akpebu Adjah and Van der Walt. "Career Progression of Female Librarians in Public University Libraries in Ghana."

54. Bin Hashim and Mokhtar, "Preparing New Era Librarians and Information Professionals: Trends and Issues," 151-55.

55. "The Global Economy."

56. Siddique et al., "Library and Information Science Research in Pakistan." 